\title{
ZMYM2/FGFR1 Fusion Protein
}

National Cancer Institute

\section{Source}

National Cancer Institute. ZMYM2/FGFR1 Fusion Protein. NCI Thesaurus. Code C99520.

A fusion protein encoded by the ZMYM2/FGFR1 fusion gene. This protein is comprised of the 10 zinc finger protein dimerization motifs from the zinc finger MYM-type protein 2 followed by the tyrosine kinase domains of the basic fibroblast growth factor receptor 1 . 